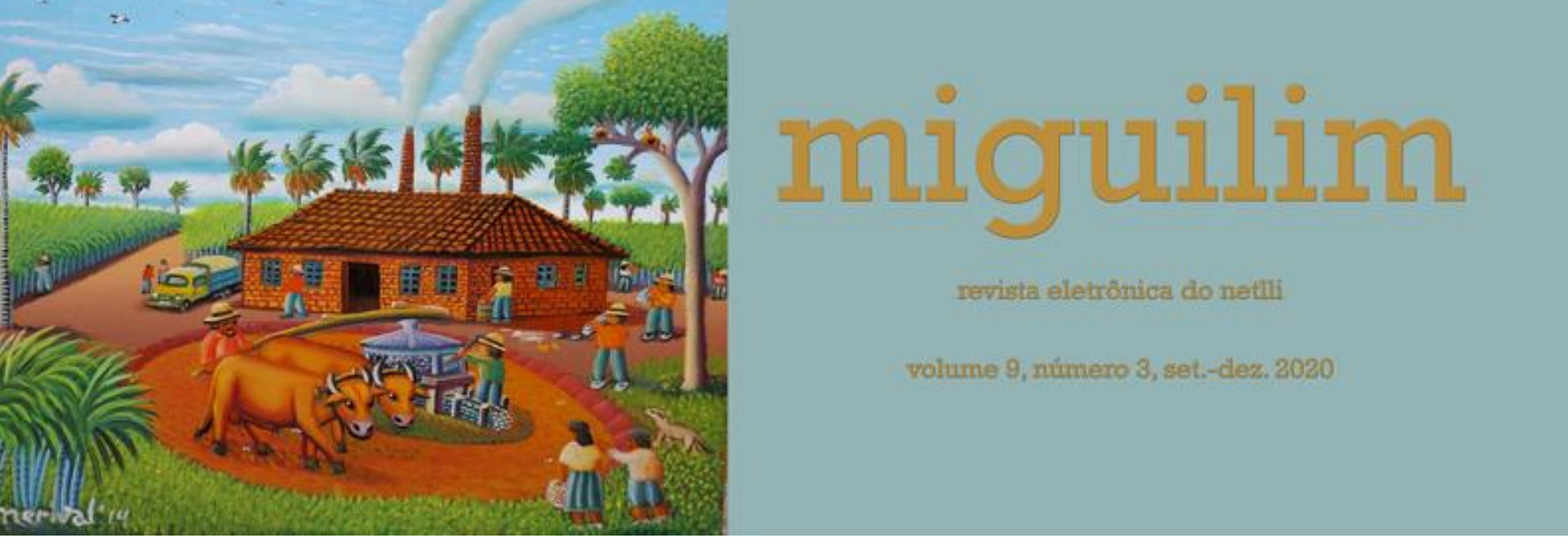

\title{
EDITORIAL: PESQUISANDO UM MUNDO EM CRISE
}

\section{EDITORIAL: RESEARCHING A WORLD IN CRISIS}

\author{
Newton de Castro PONTES \\ Universidade Regional do Cariri, Brasil
}

TEXTO | CITAR ESTE TRABALHO | O AUTOR

DOI: https://doi.org/10.47295/mgren.v9i3.3067

Texto integral

O novo número de Miguilim chega a seus leitores em um momento delicado de nossa história. Se a crise política e social no Brasil já demonstrava que poderia se agravar em 2020 (e vários artigos de nossas edições anteriores buscavam compreender os mecanismos discursivos por trás disso), o advento de uma crise mundial de saúde acelerou e intensificou o que era percebido, desde o início, como sintoma de um profundo problema em nosso tecido social, como uma quebra do próprio pacto social. Acima de tudo, os discursos de perseguição ao conhecimento científico alcançaram ampla capilaridade e atingiram o seu catastrófico ápice, propagando um negacionismo cujas consequências genocidas são, agora, sentidas. 0 que era experimentado em larga escala principalmente nas ciências humanas e sociais acabou por se estender, em 2020, para áreas normalmente prestigiadas vimos, então, os ataques atingirem também as ciências médicas e biológicas.

Como participam a teoria literária e a linguística nesse processo? 0 trabalho de pesquisar um mundo em crise envolve entender seus enunciados, incluindo os enunciados médicos e políticos e também as expressões de nossa imaginação em situações críticas. Incluímos, então, um dossiê neste número que discute as 
repercussões da pandemia e da crise política associada a ela - tais artigos abordam a literatura em condições de isolamento e no cenário pandêmico em terras colonizadas, o papel das redes sociais e os discursos de lideranças políticas, no Brasil e no exterior.

Em uma de nossas edições mais longas, apresentamos quarenta e sete artigos (incluindo nosso dossiê, temos vinte e cinco de literatura e vinte e dois de linguística), com textos em português, inglês e francês, advindos de várias instituições, que abordam ainda os mais variados temas - mostrando que a pesquisa científica e o trabalho acadêmico seguem vivos e relevantes, desenvolvendo-se (talvez ainda mais) mesmo em condições adversas.

\section{Para citar este traballho}

PONTES, Newton de Castro. Editorial: pesquisando um mundo em crise. Miguilim - Revista Eletrônica do Netlli, Crato, v. 9, n. 3, p. 295-296, set.-dez. 2020.

\section{O autor}

Newton de Castro Pontes é doutor em Letras (Teoria da Literatura) com pósdoutorado pela Universidade Federal de Pernambuco (UFPE). Possui mestrado em Literatura e Interculturalidade pela Universidade Estadual da Paraíba (UEPB) e licenciatura em Letras pela Universidade Regional do Cariri (URCA). Atualmente, é professor adjunto de Teoria da Literatura (URCA) e professor permanente no Programa de Pós-Graduação em Letras da mesma instituição. É pesquisador na área de Teoria do Conto, com ênfase atual nas literaturas hispano-americanas. 